\title{
Role of Exogenous Fibrolytic Enzymes in Ruminant Digestion - A Review
}

\author{
Mocherla, V.A.N. Suryanarayana* and P. Kavitha \\ Sri Venkateswara Veterinary University, Livestock Research Station, \\ Garividi-535 101, Andhra Pradesh, India \\ *Corresponding author
}

\begin{tabular}{|c|c|}
\hline & \multirow{7}{*}{$\begin{array}{l}\text { A B S T R A C T } \\
\text { In over three decades the increasing trend on the use of feed additives gained momentum } \\
\text { owing to a ban on antibiotic growth promoters. Total Mixed Rations form the main feed } \\
\text { source for ruminants which are rich in fibrous portion and cannot be hydrolyzed by the } \\
\text { endogenous enzymes and hence should depend on either the enzymes secreted by the } \\
\text { rumen microbes or must be supplied externally as Exogenous Fibrolytic Enzymes (EFE). } \\
\text { The ultimate function of these EFE is to supply maximum nutrients from the digestible, } \\
\text { potentially digestible and the indigestible fractions of the cell walls. However the action of } \\
\text { these enzymes differ from source to source, mode of application, dosage, type of substrate } \\
\text { and other factors. Use of EFE is gaining importance as these improve the nutrient } \\
\text { digestibility and performance without affecting the animal health. Wide knowledge on } \\
\text { rumen eco system, biotechnology, plenty availability of EFE at cheaper rates, knowing the } \\
\text { enzyme assay methods for assessing their activity also are the contributing factors for the } \\
\text { wide usage of EFE. Addition of EFE can also be a crucial component in reducing the } \\
\text { production of methane which is considered as a greenhouse gas. It was reported that the } \\
\text { more productive the animal, the less is the greenhouse gas emission. But in tropical } \\
\text { countries where most of the feed is from fibrous resources, addition of EFE is crucial since } \\
\text { the production of methane and carbon dioxide is maximum with low yielding animals. } \\
\text { However the function of EFE varies with various factors and various contradicting results } \\
\text { were reported. These inconsistent results indicate that further studies need to be undertaken } \\
\text { to demonstrate the effects of EFE on greenhouse gas emissions and microbial protein } \\
\text { synthesis. }\end{array}$} \\
\hline & \\
\hline & \\
\hline & \\
\hline Article Info & \\
\hline & \\
\hline & \\
\hline
\end{tabular}

\section{Introduction}

There is a major difference between the monogastric animals and the ruminants with respect to mode of digestion, metabolic pathways of the absorbed nutrients and the end products of the metabolism. Cellulose, hemi-cellulose, starch, fructans and pectin form the major source of carbohydrates in ruminants. Cellulose is practically indigestible by the ordinary digestive enzymes produced by the GI tract. Hence this is broken down by the micro-organisms. The end products of carbohydrate digestion in the ruminants include acetic acid, butyric acid and propionic acid. Along with these, some branched chain fatty acids like formic acid, valeric acid, iso valeric acid, isobutyric acid, 2-methyl butyric acid and caproic acid are produced in the rumen from the branched chain amino acids via oxidative deamination and oxidative decarboxylation. 
The primary difference between ruminants and non-ruminants is that ruminants' stomachs have four compartments: the rumen, reticulum, omasum, and abomasum. In the first two chambers, the food is mixed with saliva and separates into layers of solid and liquid material. Solids clump together to form the cud or bolus.

\section{Source of feed for ruminants}

Forages form the major supplier of feed for ruminants which consists of cellulose as the main component and is also the most abundant biopolymer on earth. Cellulose is made up of the beta [1-4] glycosidic bond which cannot be hydrolyzed by the enzymes secreted by ruminants.

\section{Structure of cell walls}

Plants do not have a skeleton to support themselves and so the cells are bound together by bonds. Plant cell walls are composed of cellulose (35-50\%), hemi cellulose (20-35\%) and lignin (10-15\%) and the lignifications varies as the age of the plant advances. (Paloheimo et al., 2010). Vertebrates lack the ability to hydrolyse the beta [1-4] glycosidic bond of plant cellulose due to the lack of the enzyme cellulase. Thus, ruminants must completely depend on the microbial flora, present in the rumen or hindgut, to digest cellulose. Digestion of food in the rumen is primarily carried out by the rumen microflora, which contains dense populations of several species of bacteria, protozoa, sometimes yeasts and other fungi. One $\mathrm{ml}$ of rumen is estimated to contain 10-50 billion bacteria and 1 million protozoa, as well as several yeasts and fungi.

Since the environment inside a rumen is anaerobic, most of these microbial species are obligate or facultative anaerobes that can decompose complex plant material, such as cellulose, hemicellulose, starch and proteins. The hydrolysis of cellulose results in sugars, which are further fermented to acetate, lactate, propionate, butyrate, carbon dioxide, and methane.

\section{Improving the nutritive value of forages in olden days}

Previously the digestibility of forages or crop residues was improved by the addition of caustic soda or caustic potash which were corrosive and obviously not gained popularity. In tropical countries like India, usage of forages rich in fibre has become mandatory as these are abundantly available and there is a shortage of green fodder. Under these conditions, search for other alternate feed additives which improve the forage nutrient utilization gained popularity and one of this is use of (EFE) exogenous fibrolytic enzymes.

\section{History of the use of EFE in ruminants}

Fibrolytic enzymes containing cellulase, $\beta$ glucanse, xylanase were initially used in poultry and swine diets which contain low levels of starch and higher levels of fibre in the form of non-starch polysaccharides (NSP) and resistant starch (Sauvant et al., 2004). Their inclusion in the diets at higher levels lead to the reduced performance in the growth of the animals due to the increased digesta viscosity, increased endogenous nutrient losses and reduced feed intake (Owusu et al., 2006). Further, NSP are not hydrolyzed by digestive enzymes secreted by monogastric animals (Barrera et al., 2003). The fibre matrix and nutrients entrapped in fibre usually bypass digestion limiting the nutrient digestion and absorption (Sauvant et al., 2004). They also reduce protein digestion by entrapping amino acids which make them unavailable for the digestion and absorption (Jin et al., 1994). 
Negative effects of fibre on nutrient digestion can be reduced by supplementation of multienzyme in diets such as xylanase, $\beta$ glucanase and cellulase (Degen et al., 2007). These enzymes partially hydrolyze NSP and thereby increase nutrient digestibility (Barrera et al., 2003; Nortey et al., 2007). Supplementation of multienzyme in proper combination and proportion play an important role in efficient and effective nutrient utilization of diets containing high fibre (Zijlstra et al., 2010). But now since most of the feeds are formulated under Total Mixed Ration (TMR), there is every need to improve the fibre forage digestibility. Under usual condition, the fibre especially Neutral Detergent Fibre (NDF) digestibility is not more than 50 percent unlike as seen during grain feeding in ruminants (Beauchemin et al., 2001). Usage of grains in the diets of ruminants is expensive. Obviously emphasis should be given to reduce the cost of production in terms of either milk or mutton. Here there is a need for the intervention of the EFE to reduce the cost of production by using the fibrous feeds in TMR (Barrera et al., 2003). It was reported by many workers that the addition of EFE to the TMR (Rodrigues et al., 2008; Wang et al., 2012; Salem et al., 2013) improved the digestibility of Dry matter (DM), NDF and Acid Detergent Fibre (ADF) thereby improving the productivity and feed conversion efficiency.

\section{Mode of action of EFE}

The EFE are most effective when applied in liquid form rather than in solid form prior to ingestion (Kung et al., 2002). This EFE weakens cell wall barriers that hinder microbial digestion in the rumen. EFE releases reducing sugars when added to the forages which arise from the partial solubilization of NDF and ADF even before feeding to the animals. After entering the rumen the feed particle releases more available carbohydrates and helps in enhancing the rapid microbial attachment (Yang et al., 2000). Pre-treatment of dry feeds with enzyme applied in liquid form creates a stable feed-enzyme complex even before entering the rumen similar to the findings reported by (Beauchemin et al., 2004).

It was postulated that the activity of the EFE is more in the rumen as compared to outside and the reasons are attributed to that the outside temperature, conditions of $\mathrm{p} \mathrm{H}$ and the contact substrate are not conducive for enzyme activity whereas this activity is more pronounced inside the rumen due to the following factors - there exists a synergism between various enzymes that are produced in the rumen with EFE and there is a possibility for more EFE activity in the rumen.

Yang et al., (2011) reported higher apparent DM digestibility during in vitro studies with alfalfa hay when a combination of two enzymatic products were added.

However the enzymes' actions differ from source to source of their supply. We know that the fibrolytic enzymes like those released from fungal origin (Trichoderma longibrachiatum, Asperigillus niger, Asperigillus oryzae) and those released from bacterial origin (Bacillus sps., Penicillium funiculosum) have cellulolytic and hemi cellulolytic enzyme activity

The factor of higher dosage of enzyme has shown significant effect (Reddish et al., 2007) in improving the performance since the feed/substrate attachment sites for enzymes and in turn rumen microbes have increased proportionately.

\section{Research work carried out}

Suryanarayana and Ramana (2016) have reported that addition of EFE in solubulized 
form was found better for the reason that it forms a stable complex with the feed and thus facilitates for the rumen bacterial attachment earlier for rapid action. EFE also releases soluble sugars from cell wall components and aids in increasing the rumen bacterial population especially fibrolytic bacteria reducing the lag time required for bacterial colonization for their action. They demonstrated that the higher dosage of EFE caused higher production.

It was demonstrated that addition of EFE causes partial solubulization of cell wall components releasing reducing sugars which acts as a ready source of energy for the microbes (Mc Allister et al., 2001) thereby, their rapid multiplication.

This leads to the shortening of the lag time needed for the microbial colonization with an increase in microbial attachment (Beauchemin et al., 2004).

It was also reported that the release of soluble sugars by EFE increases the production of glycocalyx by bacteria which facilitates the adhesion between bacteria themselves and between bacteria and substrate.

It was also reported (Chakeredza et al.,2002; Bala et al., 2009) that the addition of EFE was able to free the trapped nutrients in the cell wall network of roughages increasing the fermentative end products (Pinor et al., 2002) due to a change in ration of microbial bio mass and the digestible energy in the rumen

Nsereko et al., (2002) has reported that EFE in general indirectly increased the attachment of cellobiose and glucose utilizing bacteria along with the number in the rumen. Giraldo et al., (2008) reported that addition of EFE to the diets increased the rumen fibrolytic activity and this would be a probable reason for an increased performance. The factor of higher dosage of enzyme has shown significant effect (Reddish et al., 2008) since the feed/substrate attachment sites for enzymes and in turn rumen microbes have increased proportionately.

It was reported that the EFE hydrolyze feed in the rumen either alone or by a synergism with rumen microbes (Mc Allister et al., 2001).

However the rapidity in action of these EFE depends on the rumen $\mathrm{p} \mathrm{H}$. When there is more grain feeding increasing the rumen acidosis, the action of EFE decreases and the vice-versa during high rumen $\mathrm{pH}$ conditions (Beauchemin et al., 2004).

It was also reported that the attachment of microbes will be more for fibre particles and also that the number of cellobiose and glucose utilizing bacteria would be increased (Nsereko et al., 2002).

Giraldo et al., (2008) reported that addition of EFE increases the Microbial Protein synthesis which is justified that the EFE can release reducing sugars randomly which act as a ready source of available energy and promotes rapid multiplication of the microbes (Mc Allister et al.,2001).

The presence of soluble sugars will be able to supply the available carbohydrates to shorten the lag time required for the microbial colonization and also for rapid microbial attachment (Beauchemin et al., 2003).

It was reported that the EFE acts synergically with the microbes of the large intestines (Beauchemin et al., 2004).

It was concluded that the EFE can be used to alter the insoluble cell wall constituents and also to form stable enzyme substrate complexes (Salem et al., 2013; Kung Jr. et al., 2013) 
These are two illustrations on how an enzyme- substrate complex is formed
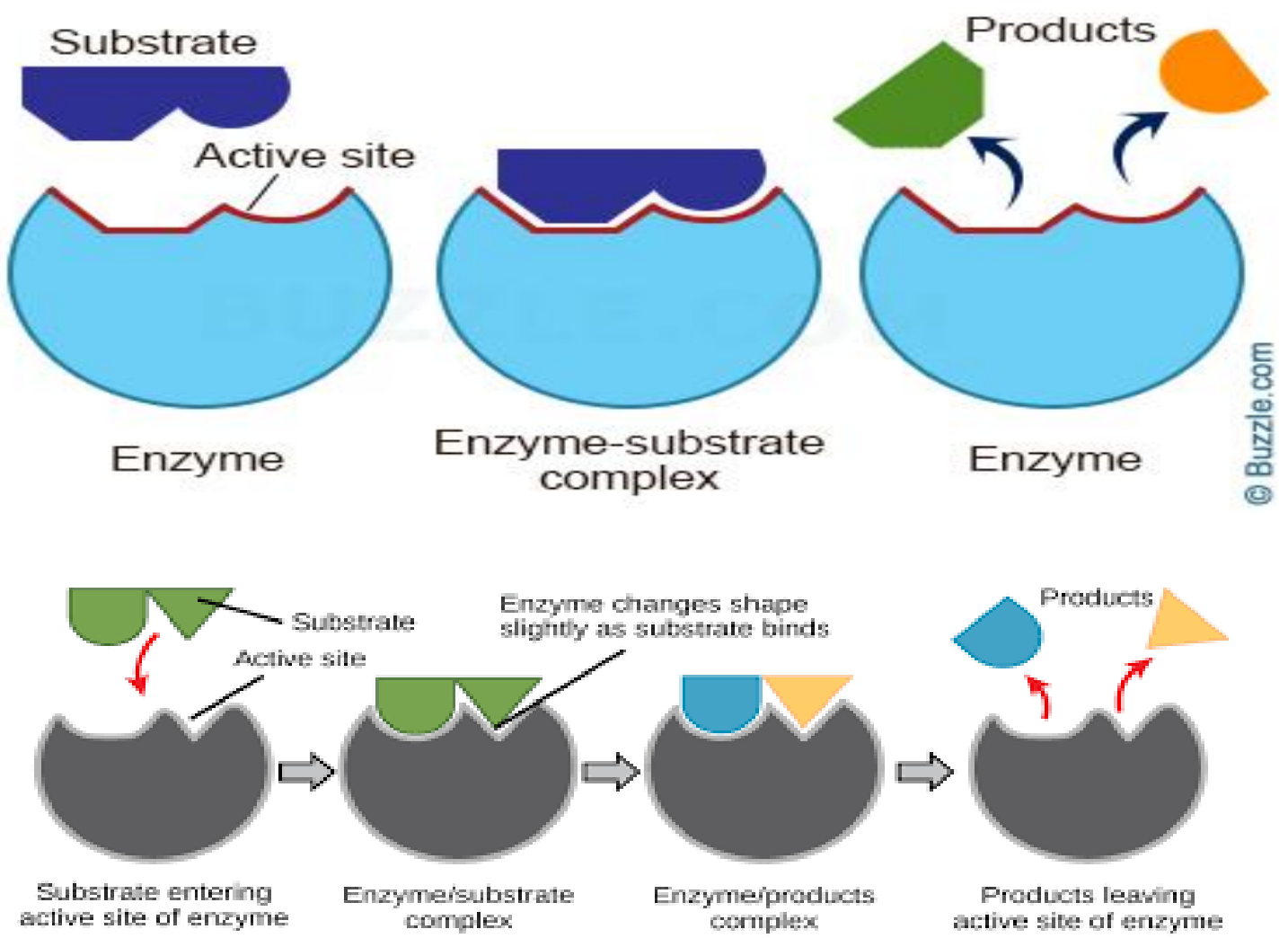

Enzyme changes shape slightly as substrate binds

Enzymefproducts complex

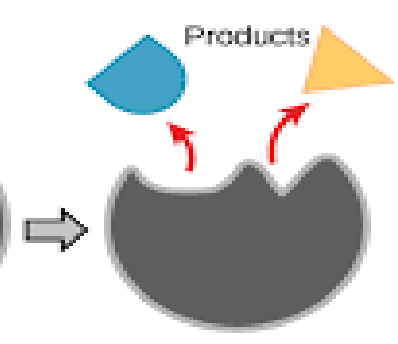

Products leaving active site of enzyme

\section{How an enzyme acts on a substrate}

When an enzyme comes in to contact with a substrate, an enzyme-substrate complex is formed which is the intermediate formed when a substrate molecule interacts with the active site of an enzyme. Following the formation of an enzyme-substrate complex, the substrate molecule undergoes a chemical reaction and is converted into a new product. Various mechanisms for the formation of enzyme-substrate complexes have been suggested, including the induced fit model and the lock and key mechanism

\section{Method of enzyme supplementation}

Methods of application can be either by spraying/top dressing or by direct infusion into the rumen. Application of EFE can be either in solid form or in a soluble form and there are many reports saying that the applying enzymes in a liquid form have a positive effect on animal performance (Kung Jr. et al., 2013; Wang et al., 2012). On the other hand direct infusion of soluble enzyme mix into the rumen (Sutton et al., 2001) was not effective. It was also reported that the incubation of the enzymes for a considerable time with the feeds before feeding to the animals improved performance. There are other possible explanations for an improved performance for the EFE added diets especially EFE applied in liquid form since formation of stable enzyme-feed complex is less prone for enzyme inactivation due to the proteolytic process in the rumen (van de Vyver and Useni, 2012; Suryanarayana and Ramana, 2016). The improved performance for solubulized enzyme supplemented groups may be due to the fact that pretreatment of feed /substrate with enzyme caused a scarring 
of the fibre particles and this effect causes easier attachment of rumen fibrolytic bacteria (Morgavi et al., 2000a)

Morgavi et al., (2000b) suggested that spraying fibrolytic enzymes on dry feeds improved rumen digestion because of a synergistic effect between the supplemented enzyme activity and ruminal enzymes. Rode et al., (1999) and Yang et al., (1999) reported improved in vivo digestion in lactating cows whereas (Kung Jr. et al., 2002; Colombatto et al., 2003) reported the same by in vitro in lactating dairy cows

The solubulized EFE fed group of animals recorded higher weight gains than those fed in dry form which may be due to the pretreatment of dry feeds with enzyme applied in liquid form created a stable feed-enzyme complex even before entering the rumen (Beauchemin et al., 2004).

The reason for higher weight gains for solubulized EFE fed animals may also be attributed to how enzymes are applied to the feeds and this would be an important factor in determining the efficacy of the enzyme (Dean et al., 2006). It was reported (Colombatto et al., 2003) that enzymes differ in their ability to degrade various substrates of specific types and have different rumen stabilities (Morgavi et al., 2000b) and probably this would be one of the reasons for inconsistent results during enzyme application to the feeds in the present study.

Elghandour et al., (2015) have concluded that the addition of cellulose and (or) xylanase to different ratios of maize silage to concentrates improved the in vitro rumen gas kinetics and cumulative gas production which indicates that the productive performance may be improved in animals. It was reported that the enzyme supplementation improved rumen fermentation and enhance attachment and colonization to the plant cell wall material by rumen microbes and there exists a synergism between the EFE and rumen enzymes.

\section{Factors on which the enzymes activity depends}

The activity of the EFE on a feed depends on various factors like source of supply of the enzymes (bacterial/fungal), type of substrate, mode of application of EFE (solid/liquid), type and stability of the enzyme, $\mathrm{p} \mathrm{H}$, temperature and the other conditions in the rumen, dose of enzymes, presence of certain enzyme inhibitors in the gut, stability conditions of EFE and the type of livestock species. Marquez et al., (2007) has stated that the activities of xylanase and cellulolytic produced from Trametes species is 5 and 7 times and 10 and 8 more active as compared to these produced from Asperigillus and Pleurotus species, respectively.

The use of EFE can be promoted in ruminant production systems by developing these at cheaper rates. In future it becomes inevitable to use these enzymes in TMR. A thorough knowledge on the potentially degradable fibre fractions and the digestion kinetics need to be known. Addition of EFE to the fibre diets may not be a tough task but this small intervention leads to the efficient utilization of nutrients and a healthy microbial balance in the rumen. However newer fibrolytic enzymes need to be prepared that can be thermo stable and can resist a p $\mathrm{H}$ of 6 to 6.8 and a temperature of $39^{\circ} \mathrm{C}$ simulating the rumen conditions. While supplementing these enzymes factors like mode of application, substrate nature, dosage, period of incubation, source of supply, etc., have to consider.

\section{References}

Bala P, Malik R, Srinivas B. Effect of fortifying concentrate supplement with 
fibrolytic enzymes on nutrient utilization, milk yield and composition in lactating goats. J Anim Sci, 2009; 80: 265-272.

Barrera M, Cervantes M, Sauer W C, Araiza A B, Torrentera N, Cervantes M. Ileal amino acid digestibility and performance of growing pigs fed wheatbased diets supplemented with xylanase. J Anim. Sci, 2004; 82:19972003.

Beauchemin K A, Colombatto D, Morgavi D. P, Yang W Z, Rode L M. Mode of action of exogenous cell wall degrading enzymes for ruminants. Can $\mathrm{J}$ Anim. Sci, 2004;. 84 (1): pp. 13-22, 2004.

Beauchemin K A, Colombatto D, Morgavi D. $\mathrm{P}$, Yang $\mathrm{W} \mathrm{Z}$. Use of exogenous fibrolytic enzymes to improve feed utilization by ruminants. J. Anim. Sci,. 2003; 81: E37-E43.

Beauchemin K A, Colombatto D, Morgavi D P. A rationale for the development of feed enzyme products for ruminants. Can. J Anim. Sci, 2004;.vol. 84, (1): pp. 23-36.

Beauchemin K A, Holtshausen L. Development in enzyme usage in ruminants, in Enzymes in Farm Animal Nutrition, M. R. Bedford and G. G. Partridge, Eds., pp., CAB International, 2010; Oxfordshire, UK, 2nd edition, 206-230.

Beauchemin K A, W. Z. Yang W Z, Rode M. Effects of barley grain processing on the site and extent of digestion of beef feed lot finishing diets J Anim. Sci, 2001; Vol. 79(7): pp. 1925-1936.

Chakeredza, S,Meulen U, Ndlovu LR. Ruminal fermentation kinetics in ewes offered a maize stover basal diet supplemented with cow pea hay, ground nut hay, cotton seed meal or maize meal. Trop Anim. Health Prod, 2002; 34: $215-230$

Colombatto D, Mould F.L.,Bhat M.K, Owen
E. Use of fibrolytic enzymes to improve the nutritive value of ruminant diets: A biochemical and in vitro rumen degradation assessment. Anim. Feed Sci Technol, 2003; 107: 201-209.

Dean D B, Adesogan A T, Staples C R, Kim SC, Little R, Effect of adding a fibrolytic enzyme to a dairy cow diet on ruminal fermentation and TMR degradation. J Dairy Sci, 2006; 89 (Suppl.1): 405 Abstract.

Degen L, Halas V, Babinszky L. Effect of dietary fibre on protein and fat digestibility and its consequences on diet formulation for growing and fattening pigs: A review. Acta Agriculturae Scandinavica, 2007; Section A-Animal Science 57:1-9.

Elghandour M M M Y, Kholif A E., Marquez Molina, Vazquez -Armijo, Anil Kumar Puniya, Salem A Z M. Influence of individual or mixed cellulase and xylanase mixture on in vitro rumen gas production kinetics of total mixed rations with different maize silage and concentrate ratios. Turkish J Vety Anim. Sci, 2015; 39:435-442

Giraldo, L.A, Tejido, M.L, Ranillo, M.J., Ramos S, Carro M D. Influence of direct Fed- fibrolytic exogenous enzymes on diet digestibility and ruminal activity in sheep fed a grass hay-based diet. J Anim. Sci. 2008; 86: 1617-1623.

Jin L, Reynolds L P, Redmer D A, Caton J S, Crenshaw J D. Effects of dietary fiber on intestinal growth, cell-proliferation, morphology in growing pigs. J Anim. Sci, 1994; 72:2270-2278.

Kung L.Jr, Cohen M.A, Rode L.M, Treacher R J. The effect of fibrolytic enzymes sprayed on to forages and fed in a total mixed ration to lactating dairy cows. $\mathbf{J}$ Dairy Sci, 2002;.85: 2396-2402.

Kung L. Jr, Treacher R J, Nouman G A, Smagala A M, Endres K M, Cohen M 
A. The effect of treating forages with fibrolytic enzymes on it's nutritive value and lactation performance of dairy cows. J Dairy Sci, 2000; 83: 112115

Márquez-Araque T, Martínez G D M, Muñoz S S G, Dios S E B, Corral O L, Fibrolytic activity of enzymes produced by Trametes sp. EUM1, Pleurotus ostreatus 1E8 and Aspergillus niger AD96.4 in solid fermentation. Interciencia, 2007.Vol. 32 (11), pp. 780-785.

Mc Allister T. A, Hristov A N, Beauchemin K A, Rode L M, Cheng KJ. Enzymes in ruminant diets. In: Enzymes in farm animal Nutrition. 2001; Eds. Bedford, M.R. \& Patridge, G.G., CAB Inter. pp 273-298.

Morgavi D.P, Beauchemin K.A, Nsereko, V L, Rode L.M, Iwassa A D, Yang, W.Z, Mc Allister T.A, Yang W. Synergy between ruminal fibrolytic enzymes and the enzymes from Trichoderma longibrachiatum. J Dairy Sci, 2000a. 83: 1310-1321.

Morgavi D.P, Newbold C J, Beever DE, Wallace RJ. Stability and stabilization of potential feed additive enzymes in rumen fluid. Enzyme microbio Technol, 2000b; 26:171-177.

Nortey T N, Patience J F, Simmins P H, Trottier N L, Zijlstra R T. Effects of individual or combined xylanase and phytase supplementation on energy, amino acid, and phosphorus digestibility and growth performance of grower pigs fed wheat-based diets containing wheat millrun. J Anim. Sci, 2007; 85: 1432-1443.

Nsereko VL, Beauchemin KA, Morgavi DP, Rode LM, Furtado AF, Mc Allister TA,Iwaasa EA, Yang WZ, Yang Y. Effect of fibrolytic enzyme preparation from Trichoderma longibrachiatum on rumen population of dairy cows. Can. $\mathrm{J}$
Micro, 2002; 48: 14-20.

Owusu- Asiedu A, Patience J F, Laarveld B, Van Kessel A G, Simmins P H, Zijlstra $\mathrm{R} T$. Effects of guar gum and cellulose on digesta passage rate, ileal microbial populations, energy and protein digestibility, and performance of grower pigs. J Anim. Sci, 2006; 84:843-852.

Paloheimo M, Piironen J, Vehmaanperä J. Xylanases and cellulases as feed additives: In Enzymes in Farm Animal Nutrition, M. R. Bedford and G. G. Partridge, Eds., pp. 12-53, CAB International, London, UK, 2nd edition, 2010.

Pinor-Rodriguez, Gonzalez J M, Mendoza S S, Barcena G D, Cobos R, Hernandez M A, Ortega M.E. Effect of exogenous fibrolytic enzyme on ruminal fermentation and digestibility of alfalfa and rye- grass hay fed to lambs. J. Anim. Sci, 2002; 80: 3016-3020.

Reddish M A, Kung Jr. L, The effect of feeding a dry enzyme mixture with fibrolytic activity on the performance of lactating cows and digestibility of a diet for sheep. J Dairy Sci, 2007; 90: 47244729.

Rode L M, Yang W Z, Beauchemin K A. Fibrolytic enzyme supplements for dairy cows in early lactation. J Dairy Sci, 1999; 82: 2121-2126.

Rodrigues M A M, Pinto P, Bezerra R M F. Effect of enzyme extracts isolated from white-rot fungi on chemical composition and in vitro digestibility of wheat straw Anim. Feed Sci. Technol, 2008; Vol. 141 (3-4): pp. 326-338.

Salem Z M, H M, Colombatto D, Elghandour M M Y. Effects of exogenous enzymes on nutrient digestibility, ruminal fermentation and growth performance in beef steers, Liv. Sci, 2013; Vol. 154 (13): pp. 69-73.

Sauvant D, Perez J M, Tran G. Wageningen Academic Publishers, Wageningen, 
2004. The Netherlands and INRA Editions, Versailles, France.

Suryanarayana MVAN, Ramana J V. Effect of feeding enzyme mixture with fibrolytic activity in dry and solubulized forms on the performance of lambs Indian J Vety Anim. Sci Res, 2016 Vol.45 (1) Jan-Feb: pp 456-459

Sutton J D, Phipps R H, Beever D E, Humphries D J, Hartnell G F, Vicini J L. Comparison of different methods of administration on the effect of fibrolytic enzymes on digestive processes in lactating cows. J Dairy Sci, 2001; 84 (Suppl.1): 37 (Abstr.)

Van de Vyver W F J, Useni B A. Digestion and microbial protein synthesis in sheep as affected by exogenous fibrolytic enzymes. South African J Anim. Sci; 2012. (Issue 5 September 1)

Wang Y, Ramirez-Bribiesca J E, Yanke, Tsang L Y, McAllister T A. Effect of exogenous fibrolytic enzyme application on the microbial attachment and digestion of barley straw in vitro Asian-Austral J Anim. Sci, 2012; Vol. 25 (1): pp. 66-74.

Yang $\mathrm{H} \mathrm{E}$, Son Y S, Beauchemin K A. Effects of exogenous enzymes on ruminal fermentation and degradability of alfalfa hay and rice straw," AsianAustral J Anim. Sci, 2011; Vol. 24 (1): pp. 56-64.

Yang W Z, Beauchemin K A, Rode L M. Effect of an enzyme feed additive on extent of digestion and milk production of lactating dairy cows. J Dairy Sci, 1999; 82: 391-403.

Yang W Z, Beauchemin K A, Rode L M. A comparison of methods of adding fibrolytic enzymes to lactating cow diets J Dairy Sci, 2000; Vol. 83 (11): pp. 2512-2520.

Zijlstra R T, Owusu-Asiedu A, Simmins P H. Future of NSP-degrading enzymes to improve nutrient utilization of coproducts and gut health in pigs. Liv. Sci. 2010. 134: 255-257.

\section{How to cite this article:}

Mocherla, V.A.N. Suryanarayana and Kavitha, P. 2017. Role of Exogenous Fibrolytic Enzymes in Ruminant Digestion - A Review. Int.J.Curr.Microbiol.App.Sci. 6(11): 1400-1408. doi: https://doi.org/10.20546/ijcmas.2017.611.167 